\title{
EVALUASI PROGRAM PENGENDALIAN FILARIASIS DARI ASPEK MANAJEMEN DI KABUPATEN ACEH JAYA PROVINSI ACEH
}

\section{EVALUATION OF FILARIASIS COUNTROL PROGRAM FROM MANAGEMENS ASPEK IN ACEH JAYA DISTRICT ACEH PROVINCE}

\author{
Yulidar $^{1 *}$, Nelly Marissa ${ }^{1}$, Veny Wilya ${ }^{1}$, Rosdiana $^{1}$, Eka Fitria $^{1}$, Ulil Amri Manik ${ }^{1}$, \\ Eka Randiana ${ }^{2}$, Ibnu Muhsi ${ }^{2}$ \\ ${ }^{1}$ Balai Penelitian dan Pengembangan Kesehatan Banda Aceh \\ Jln. Bandara Sultan Iskandar Muda, Lr. Tgk. Dilangga No.09, Lambaro, Aceh Besar \\ ${ }^{2}$ Dinas Kesehatan Kabupaten Aceh Jaya \\ Jln. Mahkota Kuala Meurusi Calang, Aceh Jaya. \\ *email: yulidaryacob@gmail.com
}

\begin{abstract}
ABSTRAK
Filariasis atau penyakit kaki gajah merupakan penyakit tular vektor yang masih endemis di Kabupaten Aceh Jaya Provinsi Aceh. Program pengendalian filariasis merujuk pada kebijakan yang sudah ditentukan oleh pemerintah pusat. Pemberian obat pencegahan massal sudah dilakukan selama 5 putaran sampai tahun 2015. Pada tahun 2016 dilakukan survei evaluasi prevalensi mikrofilaria (pre-TAS) dan hasilnya adalah Kabupaten Aceh Jaya tidak lulus survei tersebut. Penelitian ini merupakan studi kualitatif yang dilakukan pada bulan oktober 2017 dengan metode indepth interview. Jumlah responden yang diwawancara adalah 4 orang. Keberhasilan atau kegagalan eliminasi filariasis dipengaruhi oleh aspek epidemiologi dan manajemen. Aspek manajemen yang ditelusuri dalam penelitian ini yaitu bagaimana implementasi kebijakan pelaksanaan program pengendalian filariasis. Data dianalisis secara tematik. Hasil analisis data menunjukkan bahwa implementasi kebijakan pelaksanaan program pengendalian filariasis yaitu pemberian obat massal pencegahan berjalan dengan baik. Keberhasilan ini ditunjukkan oleh data cakupan minum obat pada masyarakat setiap tahunnya selalu lebih dari standar nasional. Faktor kegagalan pre-TAS belum diketahui secara pasti. Berdasarkan hasil evaluasis program dari aspek implementasi maka ketersediaan sumber daya manusia dan anggaran belum maksimal untuk pengendalian filariasis.
\end{abstract}

Kata kunci: Implementasi kebijakan, Aceh Jaya, POPM Filariasis Aceh Jaya

\section{ABSTRACT}

Filariasis or elephantiasis still an endemic vector borne disease in Aceh Jaya district Province Aceh. Prevention program of filariasis in Aceh jaya district is refers to the government policy. Mass drug administration was done during the fifth round of 2015. The survey prevalence of microfilaria (pre-TAS) in Aceh Jaya district 2016 and the result show is failed. This study is a qualitative research and conducted in oktober 2017 with indepth interview methode. The number of respondents interviewed was 4 respondents. The success or failure of filariasis elimination is influenced by epidemiological and management aspects. The management aspect traced is the implementation of the policy for prevention program of filariasis. Data were analyzed thematically. The result showed that the implementation of the policy for prevention program of filariasis is mass drug administration goes well. This success is shown by the annual data on taking medicine in community is always more than the national standard. PreTAS failure factor is not known for certain. Based on the evaluation of the program from the implementation aspect, the availability of human resources and the budget is not optimal for filariasis control.

Keywords: implementation of the policy, Aceh Jaya, MDA Filariasis Aceh Jaya 


\section{PENDAHULUAN}

Suatu negara dikatakan baik apabila memperhatikan tiga aspek kebutuhan dasar keberlangsungan kehidupan negaranya. Tiga aspek tersebut yaitu pendidikan, ekonomi dan kesehatan. Oleh karena kesehatan termasuk kebutuhan dasar manusia dan menjadi prioritas bagi kehidupan pembangunan maka negara harus membuat suatu hukum atau undangundang dalam pelaksanaannya. Adanya undang-undang No. 36 Tahun 2009 yang mengatur tentang kesehatan di Indonesia, ${ }^{1}$ semakin membuktikan bahwa begitu pentingnya kesehatan bagi masyarakat sehingga pemerintah pusat maupun daerah berkewajiban menyelenggarakan pelayanan kesehatan bagi penduduk di wilayahnya. Satu dari beberapa penyakit tular vektor yang endemis saat ini adalah filariasis.

Indonesia termasuk dalam 53 negara di dunia yang merupakan wilayah endemis filariasis, dan satu-satunya negara di dunia yang ditemukannya tiga spesies cacing filaria pada manusia yaitu: Wuchereria bancrofti, Brugia malayi dan Brugia timori. ${ }^{2-5}$ Filariasis atau penyakit kaki gajah merupakan penyakit menular menahun oleh cacing filaria yang menyerang saluran dan kelenjar getah bening, dan tergolong penyakit neglected tropical diseases yaitu penyakit tropis yang terabaikan namun masih menjadi masalah kesehatan masyarakat di berbagai belahan dunia. ${ }^{6}$

Berdasarkan Peraturan Menteri

Kesehatan Republik Indoensia Nomor 94
Tahun 2014 tentang penanggulangan filariasis, titik berat pengendalian filariasis adalah pemutusan rantai penularan dengan pemberian obat pencegahan massal (POPM). ${ }^{7}$ Sesuai Permenkes tersebut, penyelenggaraan penanggulangan filariasis dilaksanakan oleh Pemerintah, dalam hal ini Kementerian Kesehatan, dan Pemerintah Daerah dengan melibatkan peran serta masyarakat. Penanggulangan filariasis dilaksanakan dengan empat pokok kegiatan yaitu (1) surveilans kesehatan; (2) penanganan penderita; (3) pengendalian faktor risiko melalui POPM; dan (4) komunikasi, informasi, dan edukasi. ${ }^{6}$ Surveilans kesehatan mencakup penemuan penderita, survei data dasar prevalensi mikrofilaria, survei evaluasi prevalensi mikrofilaria yaitu pelaksanaan preTransmission Assessment Survei pre-TAS), dan survei evaluasi penularan (Transmission Assessment Survey/ TAS). Keberhasilan dan kegagalan eliminasi filariasis di dukung oleh banyak aspek yaitu aspek manajemen (implementasi kebijakan) dan aspek epidemiologi (host, agent, lingkungan).

Berdasarkan data dari Subdit Filariasis Kementerian Kesehatan RI, sampai tahun 2014 terdapat 241 kabupaten/ kota yang merupakan daerah endemis filariasis dan sebanyak 192 kabupaten/kota sudah melakukan POPM selama 5 putaran ( 5 tahun berturut-turut). ${ }^{8}$ Dari 241 kabupaten yang endemis tersebut 12 kabupaten diantaranya berada di Provinsi Aceh. 
Satu dari 12 Kabupaten di Provinsi Aceh yang endemis filariasis adalah Kabupaten Aceh Jaya. Setelah ditetapkan sebagai wilayah endemis filariasis, Kabupaten Aceh Jaya sudah melaksanakan program pemberian POPM secara menyeluruh. POPM dilakukan selama 5 putaran dari tahun 2011 sampai 2015 dan pada tahun 2016 dilaksanakan pre-TAS. Kegiatan pre-TAS berupa survei darah jari malam hari dengan pemeriksaan mikroskopis. Hasil kegiatan preTAS di dapatkan 5 responden di desa Desa Ligan (desa sentinel filariasis) positif Brugia malayi dalam darahnya (5 kasus baru) maka Kabupaten Aceh Jaya dinyatakan gagal preTAS. Kegagalan pre-TAS di dukung oleh banyak faktor. Penelitian ini bertujuan untuk mengetahui aspek manajemen (implementasi kebijakan) dalam program pengendalian filariasis di Kabupaten Aceh Jaya terkait kegagalan pre-TAS.

\section{METODE}

Penelitian ini merupakan studi kualitatif. Etik penelitian dikeluarkan oleh
Komisi Etik Badan Penelitian dan Pengembangan Kesehatan Nomor: LB.02.01/2/KE.266/2017. Pengumpulan data dilakukan pada bulan Oktober 2017 di Kabupaten Aceh Jaya. Data primer dikumpulkan dengan cara indepth interview (wawancara mendalam) pada 4 orang informan yaitu Kepala Puskesmas Sampoiniet, Kepala Puskesmas Setia Bakti, Kepala Seksi dan Kepala Bidang Pemberantasan dan Pengendalian Penyakit Dinas Kesehatan Kabupaten Aceh Jaya. Data sekunder berupa data cakupan POPM didapatkan dengan telaah dokumen. Parameter yang menjadi tolak ukur aspek manajemen adalah implementasi kebijakan, sumber daya manusia dan pemberdayan masyarakat, ketersediaan anggaran serta sarana-prasarana termasuk ketersediaan obat. Data di analisis secara tematik dan di interpretasikan secara deskriptif.

\section{HASIL}

Data cakupan pelaksanaan POPM di Kabupaten Aceh Jaya selama 5 tahun berturutturut disajikan dalam Tabel 1 di bawah ini.

Tabel 1. Cakupan Pengobatan Massal di Kabupaten Aceh Jaya Tahun 2011-2015

\begin{tabular}{cccccccc}
\hline & & \multicolumn{3}{c}{ Jumlah } & \multicolumn{3}{c}{ Persentase } \\
\cline { 3 - 7 } No. & Tahun & $\begin{array}{c}\text { Penduduk } \\
(\mathrm{P})\end{array}$ & $\begin{array}{c}\text { Sasaran } \\
(\mathrm{S})\end{array}$ & $\begin{array}{c}\text { Makan } \\
\text { Obat (MO) }\end{array}$ & S/P (\%) & MO/S (\%) & MO/P (\%) \\
\hline 1. & 2011 & 78.741 & 73.448 & 62.784 & $93.27 \%$ & $85,48 \%$ & $93.27 \%$ \\
2. & 2012 & 78.979 & 72.909 & 64.860 & $92.31 \%$ & $88,96 \%$ & $92.31 \%$ \\
3. & 2013 & 80.886 & 72.900 & 64.422 & $90.12 \%$ & $88.37 \%$ & $90.12 \%$ \\
4. & 2014 & 81.955 & 71.834 & 65.426 & $87.65 \%$ & $91,08 \%$ & $87.68 \%$ \\
5. & 2015 & 81.953 & 70.645 & 70.643 & $86.20 \%$ & $95,40 \%$ & $82.20 \%$ \\
6. & 2016 & - & \multicolumn{3}{c}{ Tidak Lulus Pre TAS } \\
\hline
\end{tabular}

Sumber:

* Data Dinkes Kabupaten Aceh Jaya (2017).

* Keterangan: Jumlah kecamatan: 9, Jumlah Puskesmas: 11 
Persentase cakupan pengobatan massal filariasis selama 5 putaran (5 tahun berturutturut) dari tahun 2011 sampai 2015 selalu lebih dari standar nasional yaitu $65 \%$ jumlah penduduk dan $85 \%$ jumlah penduduk sasaran. Jumlah penduduk sasaran yang makan obat dari $85,48 \%$ pada 2011 terus meningkat mencapai $95,40 \%$ di tahun 2015. Pada tahun 2016 dilakukan uji pre-TAS pada 600 penduduk di dua desa yaitu desa sentinel dan spot survei filariasis. Hasil survei ditemukan 5 kasus baru filariasis Brugia malayi ( $\mathrm{mf}$ rate $0,84 \%<1 \%$ ) di desa sentinel yaitu Desa Ligan. Oleh karena ditemukannya kasus baru filariasis di Desa Ligan maka Kabupaten Aceh Jaya disimpulkan gagal uji pre-TAS dan harus melakukan POPM 2 putaran lagi.

Data transkripsi wawancara dengan informan ditampilkan dalam Tabel 2.

Tabel 2. Verbatin indepth interview informan program pengendalian filariasis dari aspek manajemen di Kabupaten Aceh Jaya, tahun 2017.

\begin{tabular}{|c|c|c|c|c|c|}
\hline No & Bahan diskusi & Informan 1 & Informan 2 & Informan 3 & Informan 4 \\
\hline \multicolumn{6}{|c|}{ Aspek kebijakan : } \\
\hline 1. & $\begin{array}{l}\text { Bagaimana } \\
\text { translasi kebijakan } \\
\text { pemerintah pusat } \\
\text { dalam eliminasi } \\
\text { filariasis }\end{array}$ & $\begin{array}{l}\text { Translasi } \\
\text { kebijakan } \\
\text { Pemerintah } \\
\text { Pusat dalam } \\
\text { eliminasi } \\
\text { filariasis yaitu } \\
\text { pengobatan } \\
\text { massal } \\
\text { dilakukan setiap } \\
\text { tahun sekali, } \\
\text { dalam waktu } \\
\text { minimal } 5 \\
\text { tahun berturut- } \\
\text { turut sudah } \\
\text { sangat baik }\end{array}$ & $\begin{array}{l}\text { Setiap kebijakan } \\
\text { pasti dibuat } \\
\text { sebaik mungkin } \\
\text { termasuk untuk } \\
\text { eliminasi } \\
\text { filariasis. } \\
\text { Diharapkan 2020, } \\
\text { Indonesia sudah } \\
\text { eliminasi. } \\
\text { Kegiatan-kegiatan } \\
\text { untuk mendukung } \\
\text { eliminasi filariasis } \\
\text { itu sudah di bahas } \\
\text { dalam pertemuan- } \\
\text { pertemuan (baik } \\
\text { tingkat kabupaten } \\
\text { maupun tingkat } \\
\text { provinsi). }\end{array}$ & $\begin{array}{l}\text { Dalam hal ini } \\
\text { Dinas kesehatan } \\
\text { telah berupaya } \\
\text { dengan maksimal } \\
\text { tetapi masalah } \\
\text { eliminasi filariasis } \\
\text { ini masih terdapat } \\
\text { banyak kendala } \\
\text { dan hambatan } \\
\text { khususnya dalam } \\
\text { hal pemberian } \\
\text { obat pencegahan } \\
\text { massal } \\
\text { disebabkan masih } \\
\text { adanya } \\
\text { masyarakat yang } \\
\text { tidak mau minum } \\
\text { obat }\end{array}$ & $\begin{array}{l}\text { Implementa } \\
\text { si kebijakan } \\
\text { dinas dalam } \\
\text { eliminasi } \\
\text { filariasis } \\
\text { sangat baik, } \\
\text { melakukan } \\
\text { advokasi ke } \\
\text { DPR } \\
\text { kabupaten. }\end{array}$ \\
\hline 2. & $\begin{array}{l}\text { Bagaimana } \\
\text { dukungan } \\
\text { pemerintah daerah } \\
\text { terhadap kebijakan } \\
\text { eliminasi } \\
\text { pemerintah pusat? }\end{array}$ & $\begin{array}{l}\text { kabupaten } \\
\text { menyanggupi } \\
\text { untuk ikut } \\
\text { melaksanakan } \\
\text { elimanasi 2020, } \\
\text { dengan masih } \\
\text { ditemukannya } \\
\text { kasus positif } \\
\text { pada } 2016 \\
\text { kemarin } \\
\text { menjadi PR } \\
\text { besar dinkes }\end{array}$ & $\begin{array}{l}\text { Pemerintah } \\
\text { daerah sangat } \\
\text { mendukung dan } \\
\text { berkomitmen } \\
\text { untuk program } \\
\text { eliminasi } \\
\text { filariasis. }\end{array}$ & $\begin{array}{l}\text { Pemerintah } \\
\text { kecamatan sangat } \\
\text { mendukung } \\
\text { terhadap } \\
\text { kebijakan } \\
\text { eliminasi } \\
\text { pemerintah pusat. } \\
\text { Dalam hal ini } \\
\text { pemerintah } \\
\text { kecamatan telah } \\
\text { memberikan } \\
\text { dukungan }\end{array}$ & $\begin{array}{l}\text { Dukungan } \\
\text { kecamatan } \\
\text { sangat baik } \\
\text { dalam } \\
\text { eliminasi } \\
\text { filariasis, } \\
\text { dari pak } \\
\text { Camat, } \\
\text { kader dan } \\
\text { aparatur } \\
\text { desa } \\
\text { bekerjasama }\end{array}$ \\
\hline
\end{tabular}




\begin{tabular}{|c|c|c|c|c|c|}
\hline No & Bahan diskusi & Informan 1 & Informan 2 & Informan 3 & Informan 4 \\
\hline & & $\begin{array}{l}\text { untuk } \\
\text { mempertegas } \\
\text { kerjasama lintas } \\
\text { sektor dalam } \\
\text { upaya minum } \\
\text { obat masal } \\
\text { bersama }\end{array}$ & & $\begin{array}{l}\text { terhadap kepala } \\
\text { desa untuk } \\
\text { memberikan } \\
\text { arahan kepada } \\
\text { masyarakat untuk } \\
\text { melaksanakan } \\
\text { pemeriksaan } \\
\text { darah dan minum } \\
\text { obat }\end{array}$ & $\begin{array}{l}\text { dalam } \\
\text { melakukan } \\
\text { eliminasi }\end{array}$ \\
\hline
\end{tabular}

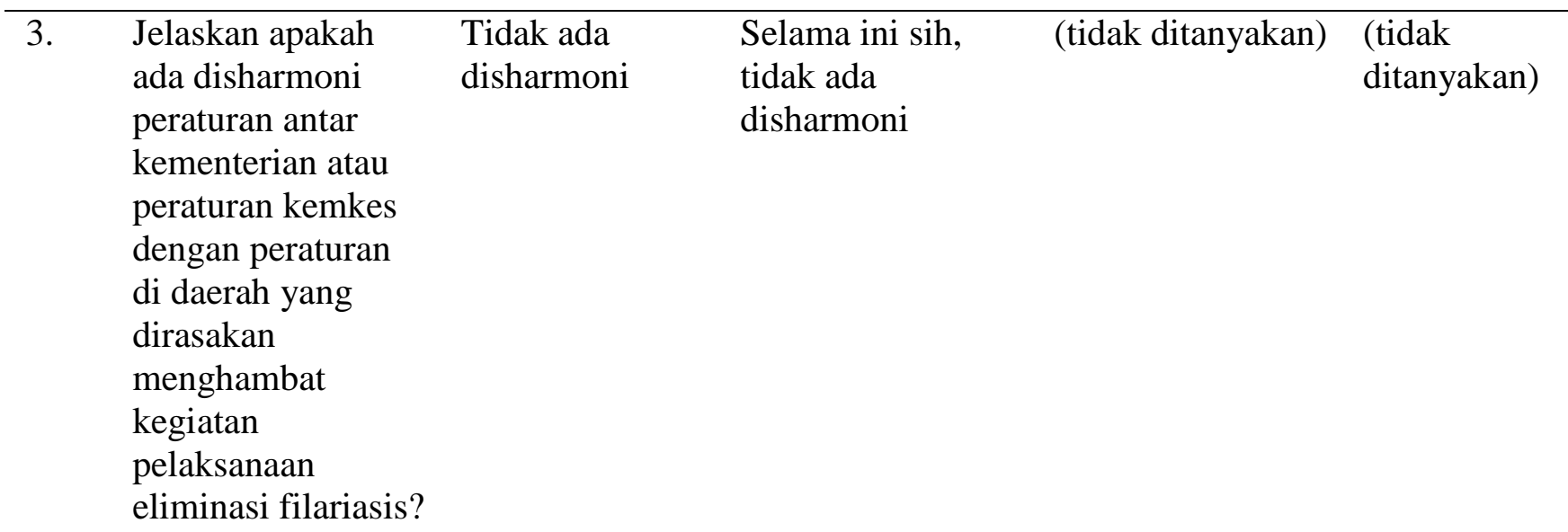

\begin{tabular}{|c|c|c|c|c|}
\hline \multicolumn{5}{|c|}{ Aspek sumber daya manusia } \\
\hline $\begin{array}{ll}4 . & \text { Bagaimana } \\
& \text { kecukupan SDM } \\
& \text { jumlah dalam } \\
& \text { kegiatan eliminasi } \\
& \text { filariasis? }\end{array}$ & $\begin{array}{l}\text { SDM sejak } \\
\text { moratorium } \\
\text { PNS sangat } \\
\text { kurang di } \\
\text { daerah, karena } \\
\text { banyak tenaga } \\
\text { PNS yang } \\
\text { sudah pensiun. } \\
\text { Saat } \\
\text { pelaksanaan } \\
\text { POPM, kita } \\
\text { berdayakan } \\
\text { masyarakat. }\end{array}$ & $\begin{array}{l}\text { Untuk SDM, } \\
\text { karena kita } \\
\text { berhubungan } \\
\text { dengan } \\
\text { laboratorium, } \\
\text { jumlah yang } \\
\text { tenaga } \\
\text { mikroskopisnya } \\
\text { sangat kurang. } \\
\text { Dari } 10 \\
\text { puskesmas yang } \\
\text { ada } \\
\text { laboratoriumnya } \\
\text { (kalau saya tidak } \\
\text { salah), } 4 \text { yang ada } \\
\text { tenaga } \\
\text { mikroskopisnya } \\
\text { PNS (2017). }\end{array}$ & $\begin{array}{l}\text { Mengenai } \\
\text { masalah SDM, } \\
\text { masih sangat } \\
\text { kurang, } \\
\text { mengingat daerah } \\
\text { yang cukup luas } \\
\text { dan jumlah } \\
\text { masyarakat yang } \\
\text { banyak. }\end{array}$ & $\begin{array}{l}\text { Sangat } \\
\text { cukup } \\
\text { jumlah } \\
\text { SDM dalam } \\
\text { melakukan } \\
\text { eliminasi } \\
\text { filariasis }\end{array}$ \\
\hline
\end{tabular}

\begin{tabular}{|c|c|c|c|c|c|}
\hline \multicolumn{6}{|c|}{ Sarana dan prasarana } \\
\hline 5. & $\begin{array}{l}\text { Bagaimana sarana } \\
\text { dan prasarana } \\
\text { dalam menunjang } \\
\text { pelaksanaan } \\
\text { eliminasi filariasis } \\
\text { (kondisi, } \\
\text { kecukupan) }\end{array}$ & $\begin{array}{l}\text { kendala sarana } \\
\text { tidak begitu } \\
\text { urgent } \\
\text { mikroskop ada } \\
\text { tetapi tenaga } \\
\text { mikroskopisnya } \\
\text { yang kurang. }\end{array}$ & $\begin{array}{l}\text { Untuk filariasis, } \\
\text { mungkin lebih ke } \\
\text { sarana } \\
\text { laboratoriumnya. } \\
\text { Mikroskop, ruang } \\
\text { pemeriksaan kita } \\
\text { punya, di semua }\end{array}$ & $\begin{array}{l}\text { Untuk obat- } \\
\text { obatan salama ini } \\
\text { disediakan dari } \\
\text { Dinas Kesehatan }\end{array}$ & $\begin{array}{l}\text { Ada } \\
\text { sarananya, } \\
\text { dirasakan } \\
\text { cukup untuk } \\
\text { alat } \\
\text { transportasi }\end{array}$ \\
\hline
\end{tabular}




\begin{tabular}{|c|c|c|c|c|c|}
\hline No & Bahan diskusi & Informan 1 & Informan 2 & Informan 3 & Informan 4 \\
\hline & & & $\begin{array}{l}\text { puskesmas kita } \\
\text { punya, cuma } \\
\text { memang } \\
\text { tenaganya tidak } \\
\text { semua puskesmas } \\
\text { punya. }\end{array}$ & & \\
\hline \multicolumn{6}{|c|}{ Kerjasama lintas sektor } \\
\hline 6. & $\begin{array}{l}\text { Bagaimana proses } \\
\text { koordinasi lintas } \\
\text { sektor dan lintas } \\
\text { program? apa } \\
\text { kendala yang } \\
\text { dihadapi? }\end{array}$ & $\begin{array}{l}\text { Lintas sektor } \\
\text { sangat } \\
\text { mendukung, } \\
\text { misalnya ikut } \\
\text { bekerjasama } \\
\text { dalam kegiatan } \\
\text { didesa, turut } \\
\text { membantu } \\
\text { kegiatan di } \\
\text { desa. Lintas } \\
\text { sektornya } \\
\text { adalah ada, } \\
\text { yaitu dinas } \\
\text { pendidikan, } \\
\text { camat, kodim, } \\
\text { polres }\end{array}$ & $\begin{array}{l}\text { Dengan lintas } \\
\text { sektor kita tidak } \\
\text { ada masalah, saat } \\
\text { pertemuan, } \\
\text { anggota dewan } \\
\text { kita undang dan } \\
\text { mereka hadir, } \\
\text { bahkan banyak } \\
\text { masukan dan } \\
\text { saran dari mereka } \\
\text { untuk segera } \\
\text { melakukan } \\
\text { tindakan untuk } \\
\text { eliminasi } \\
\text { filariasis. }\end{array}$ & $\begin{array}{l}\text { Koordinasi lintas } \\
\text { sektor dan lintas } \\
\text { program berjalan } \\
\text { dengan baik. } \\
\text { Dalam eliminasi } \\
\text { filaria ini seluruh } \\
\text { anggota } \\
\text { masyarakat } \\
\text { diikutsertakan } \\
\text { termasuk PKK } \\
\text { dan perangkat } \\
\text { desa dilibatkan } \\
\text { dalam hal ini }\end{array}$ & $\begin{array}{l}\text { Melakukan } \\
\text { kerjasama } \\
\text { dengan } \\
\text { Koramil, } \\
\text { Polsek, Pak } \\
\text { Camat, } \\
\text { Kader dan } \\
\text { PKK }\end{array}$ \\
\hline 7. & $\begin{array}{l}\text { Apakah dinas } \\
\text { kesehatan } \\
\text { melakukan } \\
\text { kerjasama dengan } \\
\text { sektor non } \\
\text { kesehatan dalam } \\
\text { eliminasi filariasis? }\end{array}$ & $\begin{array}{l}\text { Ada, yaitu } \\
\text { pembentukan } \\
\text { komda/ komisi } \\
\text { daerah } \\
\text { (Masyarakat } \\
\text { yang peduli } \\
\text { filariasis). }\end{array}$ & $\begin{array}{l}\text { Bantuan RTI } \\
\text { melalui P2P } \\
\text { Pusat. }\end{array}$ & $\begin{array}{l}\text { (Tidak } \\
\text { ditanyakan) }\end{array}$ & $\begin{array}{l}\text { (Tidak } \\
\text { ditanyakan) }\end{array}$ \\
\hline
\end{tabular}

Berdasarkan hasil analisis secara tematik, kesimpulan terhadap hasil wawancara seperti berikut:

\section{Aspek komitmen dan kebijakan}

Aspek komitmen dan kebijakan terkait eliminasi filariasis di Kabupaten Jaya dijaring dalam pendapat tentang bagaimana translasi kebijakan pemerintah pusat/ provinsi. Hasil analisis tematik menunjukkan bahwa selama ini, pelaksanaan POPM dilaksanakan sesuai arahan. POPM sudah dilakukan selama 5 tahun berturut-turut. Pemerintah daerah sangat mendukung program eliminasi filariasis. Oleh karena tahun 2016 masih ditemukan positif cacing mikrofilaria dalam masyarakat (saat pre-TAS) maka Dinas Kesehatan Kabupaten Aceh Jaya berkomitmen bahwa kerjasama lintas sektor harus lebih ditingkatkan dari sebelumnya. Menurut responden, faktor yang selalu menjadi penghambat adalah faktor dana. Ketersediaan anggaran untuk operasional kegiatan tidak mencukupi. Untuk mengatasi hal ini maka beberapa program penyuluhan terhadap filariasis terhadap masyarakat dilakukan pada saat ada kegiatan yang lain. Implementasi kebijakan pengendalian 
filariasis yang selama ini diterapkan tidak ditemukan disharmoni atau ketidaksesuaian antara kebijakan pemerintah pusat dengan kearifan lokal masyarakat.

\section{Aspek sumber daya manusia}

Tingkat kecukupan sumber daya manusia atau tenaga kesehatan yang khusus mengelola filariasis di Kabupaten Aceh Jaya masih kurang terutama petugas laboratorium (teknisi mikroskopis). Dari sebanyak 10 puskesmas, tenaga laboratorium (teknisi mikroskopis filariasis) yang tersedia hanya di 4 puskesmas masing-masing 1 orang.

Jumlah SDM atau tenaga kesehatan tidak berbanding lurus dengan luasnya lokasi dan jumlah penduduk yang harus dijangkau atau didatangi langsung oleh petugas kesehatan. Kompetensi tenaga kesehatan masih terbatas dan belum mendapatkan pelatihan khusus filariasis terutama tenaga laboratorium. Tenaga kesehatan di puskesmas selama ini hanya terpapar tentang mikroskopis filariasis bila ada kunjungan dari tim pusat. Tenaga kesehatan yang sudah pernah dilatih dan terpapar tentang filariasis hanya tenaga dari Kabupaten. Tenaga yang sudah dilatih belum maksimal untuk melatih tim tenaga kesehatan di puskesmas. Kegiatan dalam masyarakat yaitu kader dan perangkat desa sudah sangat membantu dalam memberikan arahan dan bimbingan tentang bagaimana pengendalian filariasis dari aspek vektor. Tokoh masyarakat dan kader bertanggung jawab dalam mengkoordinir dan memantau minum obat di depan petugas bagi masyarakat yang tidak hadir saat POPM serentak dilaksanakan. Pelaksanaan POPM berkoordinasi dengan lintas sektoral baik muspida dan muspika kecamatan lainnya.

3. Aspek sarana dan prasarana

Ditinjau dari aspek sarana dan prasarana kesehatan untuk mendukung pelaksanaan eliminasi filariasis di puskesmas di Kabupaten Aceh Jaya sudah memadai. Sarana prasarana utama pendukung adalah mikroskop sudah ada di semua puskesmas. Tidak terdapat kendala terhadap saranaprasarana pendukung eliminasi filariasis. Ketersediaan obat tidak menjadi kendala karena obat untuk program POPM diperoleh dari Dinas Kesehatan Provinsi Aceh sesuai dengan sasaran yang dilaporkan.

4. Aspek kerjasama lintas sektoral

Lintas sektor kesehatan atau non kesehatan Kabupaten Aceh Jaya berkomitmen untuk mensukseskan program eliminasi filariasis. Lintas sektor ikut berkomitmen bersama dalam beberapa pertemuan. Tokohtokoh dalam lintas sektor ikut mensuksesskan kegiatan minum obat bersama dengan masyarakat pada saat POPM. Kerjasama profesional yang terbentuk saat ini di Kabupaten Aceh Jaya adalah komisi daerah peduli filariasis (KOMDA).

\section{PEMBAHASAN}

Terbentuknya Kabupaten Aceh Jaya berdasarkan Undang-Undang Nomor 4 Tahun 2002 dan PERDA Nomor 5 Tahun 2002. Secara geografis, Aceh Jaya yang terletak pada 
ordinat 04'22-05'16' Lintang Utara dan 0'95'10'-96'03' Bujur Timur merupakan wilayah pesisir Barat pantai Sumatera dengan panjang garis pantai $\pm 160 \mathrm{~km}$. Demografi wilayah berupa daerah hutan, persawahan, perkebunan dan pesisir pantai. Letak Aceh Jaya berbatasan dengan Kabupaten Aceh Besar dan Pidie disebelah Utara, Kabupaten Aceh Barat sebelah Selatan dan Timur serta Samudera India, Samudera Indonesia disebelah Barat. Wilayah administratif dibagi 9 kecamatan yaitu Kecamatan Jaya, Krueng Sabe, Panga, Sampoiniet, Setia Bakti, Teunom, Indra Jaya, Darul Hikmah dan Pasi Raya. ${ }^{9}$

Manajemen pelaksanaan program eliminasi filariasis yang saat ini dilakukan adalah implementasi Permenkes No 95 Tahun 2014 tentang pengendalian filariasis. Langkah awal tahapan eliminasi filariasis berupa POPM. Persentase cakupan minum obat (lebih dari standar nasional) selama 5 putaran menggambarkan bahwa implementasi kebijakan pelaksanaan program eliminasi filariasis di Kabupaten Aceh Jaya berjalan dengan baik. Hal ini juga terjadi di Negara Ethiopia, lima kabupaten yang endemis filariasis terintegritas dengan onchocerciasis menunjukkan signifikan kemajuan selama pengobatan 6 tahun mencapai cakupan 100\% di tahun 2016. Ini membuktikan bahwa status implementasi pelaksanaan program nasional limfatik filariasis menunjukkan bahwa Ethiopia siap untuk mencapai tujuan penghapusan LF tahun 2020. ${ }^{10}$ Implementasi kebijakan pelaksanaan POPM (MDA: Mass
Drug Administration) di Myanmar dan Republic Congo juga berjalan dengan baik. Prevalensi limfatik filariasis berkurang setelah 3 putaran POPM di Myanmar dan cakupan minum obat mencapai $80 \%$ selama 5 putaran di Republic Congo. Untuk menuju elimiasi filariasis nasional dan global, Myamnar sudah membuat langkah positif dengan terus mempertahankan dukungan dan kerjasama internasional. ${ }^{11,12}$

Secara umum, implementasi kebijakan pelaksanaan POPM di Kabupaten Aceh Jaya berjalan baik. Namun terkait hal ini, bukan berarti tidak adanya faktor penghambat dalam pelaksanaan POPM. Kegagalan pre-TAS membuktikan bahwa ada faktor penghambat eliminasi filariasis di Kabupaten Aceh Jaya. Pada keempat tematik yang dianalisis, bahwa faktor penghambat yang dialami oleh Dinkes Aceh Jaya adalah keterbatasan sumber daya manusia (SDM) dan kurangnya tenaga yang berkompeten di bidang filariasis terutama tenaga laboratorium. Kekurangan sumber daya manusia dalam pelaksanaan program filariasis juga terjadi di Kabupaten Labuhanbatu Selatan. ${ }^{13}$ Keterbatasan ini juga dipengaruhi oleh wilayah demografi Kabupaten Aceh Jaya yang sangat luas sehingga memerlukan keterlibatan tenaga kesehatan yang banyak. Solusi yang dilakukan oleh Dinkes Aceh Jaya untuk mengantisipasi hal tersebut adalah dengan pemberdayaan masyarakat atau kader desa. Tenaga pelayanan kesehatan saja tidak cukup untuk mendistribusikan obat partisipasi dari masyarakat, sukarelawan dan staf 
pemerintah tingkat desa dilibatkan dalam kegiatan pemberian obat filariasis. Partisipasi dan perilaku kerja kader yang baik merupakan satu diantara daya ungkit pencapaian target cakupan POPM. ${ }^{14,15}$

Kegiatan surveilans diperlukan untuk mengamati secara terus menerus perkembangan kasus baru serta faktor resiko terjadinya penularan sesuai fakta di lapangan. Saat ini, kader atau surveilans di Dinkes Aceh Jaya hanya membantu dalam program pengobatan sedangkan untuk evaluasi pasca pemberian obat (POPM) belum ada tata laksananya. Kegiatan surveilans hanya terfokus pada surveilans pengobatan, untuk surveilans "case finding" belum dilaksanakan secara optimal. ${ }^{16}$ Hal ini dapat menjadi satu diantara beberapa penyebab kegagalan preTAS di Kabupaten Aceh Jaya. Merujuk pada pendapat Anorital, penurunan prevalensi kecacingan (termasuk filariasis) pada kabupaten/ kota yang melaksanakan POPM filariasis tidak dapat diketahui secara pasti, hal ini dikarenakan tidak ada peraturan daerah yang terkait dengan eliminasi filariasis dan pengendalian kecacingan baik di tingkat provinsi maupun tingkat kabupaten/kota untuk pelaksanaan stool survey. ${ }^{17}$

Faktor pendukung kegiatan pelaksanaan program eliminasi filariasis (POPM) adalah ketersediaan dana. Biaya yang timbul untuk program pengendalian filariasis dibebankan pada anggaran pemerintah daerah atau sumber dana lainnya yang sah sesuai dengan peraturan yang berlaku. ${ }^{6}$ Kurangnya promosi termasuk kampanye masa bulan eliminasi kaki gajah, anggaran yang minim dan dukungan dari Badan Legislatif dalam penganggaran merupakan faktor penentu keberhasilan pengendalian filariasis. ${ }^{18-20}$ Untuk itu diperlukan ditingkatkan promosi kesehatan terutama dalam hal pengendalian filariasis. Menurut Erlan, promosi kesehatan melalui penyuluhan ke masyarakat dalam kapasitas peningkatan pengetahuan masyarakat dan perubahan perilaku sehigga memepngaruhi pemutusan rantai penularan filariasis. $^{21}$

Pendapatan daerah Kabupaten Aceh Jaya belum maksimal, maka ketersediaan anggaran untuk program pengendalian filariasis masih kecil. Hal tersebut mempengaruhi kelancaran operasioanal tim saat ke desa. Kerjasama lintas sektor di Kabupaten Aceh Jaya sudah dibentuk komisi daerah untuk pengendalian tular vektor termasuk filariasis. Sarana-prasarana obat untuk filariasis tidak menjadi kendala. Obat untuk POPM yaitu kombinasi tablet Diethylcarbamazine (DEC) $100 \mathrm{mg}$ dan tablet Albendazole $400 \mathrm{mg}$ didapatkan dari Dinas Kesehatan Provinsi Aceh dan juga lembaga donor.

\section{KESIMPULAN}

Hasil analisis implementasi kebijakan pelaksanaan program eliminasi filariasis di Kabupaten Aceh Jaya Provinsi Aceh : 
1. Implementasi kebijakan pelaksanaan pemberian obat pencegahan massal filariasis berjalan dengan baik.

2. Kegagalan Pre-TAS (Tahun 2016) bukan disebabkan oleh aspek manajemen.

3. Dukungan dari pemerintah pusat berjalan dengan baik meskipun ketersediaan sumber daya manusia dan kualitas kompetensi ilmu dibidang filariasis belum memadai.

\section{SARAN}

Berdasarkan sudut pandang manajemen bahwa implemenasi kebijakan pelaksanaan program pengendalian filariasis di Kabupaten Aceh Jaya berjalan dengan baik, maka faktor kegagalan pre-TAS perlu dikaji lebih lanjut dari dari aspek yang lainnya.

\section{UCAPAN TERIMAKASIH}

Ucapan terimkasih yang sebesarbesarnya dipersembahkan kepada Kepala Badan Penelitian dan Pengembangan Kesehatan Jakarta, Kepala Puslitbang Upaya Kesehatan Masyarakat Badan litbang Jakarta, Kepala Balai litbang Kesehatan Banda Aceh, Kepala Dinas Kesehatan Provinsi Aceh, Kepala Dinas Kesehatan Kabupaten Aceh Jaya serta teman-teman tim peneliti yang telah menyelesaikan penelitian ini.

\section{DAFTAR PUSTAKA}

1. Presiden Republik Indonesia, Yudhoyono DHSB. Undang-Undang Republik Indonesia Nomor 36 Tahun 2009 Tentang Kesehatan. Jakarta: Republik Indonesia; 2009.

2. Ditjen PP \& PL. Pedoman Program Eliminasi Filariasis Di Indonesia.
Jakarta: Ditjen PP \& PL, Depkes RI. Jakarta,; 2009.

3. Masriza. Penyakit Filariasis. JKMA (Jurnal Kesehat Masy Andalas) (Andalas J Public Heal. 2012;7(1):3238. doi:10.24893/jkma.7.1.32-38.2012

4. Fauziah, Yasmin Y, Dharma W. Analisis nyamuk vektor filariasis di tiga Kecamatan Kabupaten Pidie Nanggroe Aceh Darussalam. J Biol Edukasi. 2011;3(1):26-30.

5. Yulidar. Populasi Nyamuk yang Berpotensi sebagai Vektor Filariasis di Kabupaten Aceh Utara. $J$ Biot. 2018;6(1):70-74.

6. Menteri Kesehatan Republik Indonesia. Pedoman Penanggulangan Filariasis.; 2014.

7. WHO. Global Programme to Eliminate Monitoring and Of Mass Drug Adminstration.; 2011.

8. Subdit Filariasis dan Kecacingan DiP\& P. Data Endemisitas Filariasis Di Indonesia Sampai Dengan Bulan Juli 2014. Jakarta; 2014.

9. Pemerintah Kabupaten Aceh Jaya. Profil Kabupaten Aceh Jaya.; 2013.

10. Mengistu B, Deribe K, Kebede F, et al. Europe PMC Funders Group The National Programme to Eliminate Lymphatic Filariasis from Ethiopia. $J$ Eur PMC Funders Gr. 2017;55(Suppl 1):45-54.

11. Aye NN, Lin Z, Lon KN, et al. Mapping and modelling the impact of mass drug adminstration on filariasis prevalence in Myanmar. 2018:1-11.

12. Pion SDS, Chesnais CB, Weil GJ, et al. Effect of 3 years of biannual mass drug administration with albendazole on lymphatic filariasis and soil-transmitted helminth infections : a community-based study in Republic of the Congo. 2012;17:763-769. doi:10.1016/S14733099(17)30175-5

13. Harahap R. Analisis Implementasi Kebijakan Program Eliminasi Filariasis Di Kabupaten Labuhan Batu Selatan. 2014.

14. Ipa M, Astuti EP, Yuliasih Y, et al. Kinerja Kader Kesehatan dalam Pengobatan Massal Filariasis di 
Kecamatan Cibeureum dan Cibingbin , Kabupaten Kuningan. $J$ Media Litbangkes. $\quad 2018 ; 28(1): 1-8$. doi:10.22435/mpk.v28i1.5954.1-8

15. Ramaiah KD, Kumar KNV, Chandrakala A V, Augustin DJ, Appavoo NC, Das PK. Effectiveness of community and health servicesorganized drug delivery strategies for elimination of lymphatic ${ }^{\circledR}$ lariasis in rural areas of Tamil Nadu , India. J Trop Med Int Heal. 2001;6(12):1062-1069.

16. Ipa M, Astuti EP, Ruliansyah A, Wahono T, Hakim L. Gambaran Survelens Filariasis di Kabupaten Bandung Provinsi Jawa Barat. J Ekol Kesehat. 2014;Vol. 13, N:153-164.

17. Anorital, Dewi RM, Palupi K. Studi Kajian Upaya Pemberian Obat Pencegah Masal Filariasis Terhadap Pengendalian Penyakit Infeksi Kecacingan. J Biotek
Medisiana Indones. 2016;5(2):95-103.

18. Waris L. Evaluasi kebijakan program pemberantasan filariasis. Bul Penelit Sist Kesehat. 2008;11(3):289-296.

19. Onggang FS, Kupang JK, Kupang PK. Evaluasi Implementasi " POMP " Filariasis Dan Faktor Yang Berhubungan Dengan Permasalahannya Di Kabupaten Manggarai Timur Tahun 2017 F. J Info Kesehat. 2017;15(1):4569.

20. Tyas SR, Hafiar H, Pemilihan K, Kabupaten U, Padjadjaran U. Manajemen kampanye eliminasi kaki gajah dalam upaya peningkatan kesehatan di kabupaten bogor campaign management of elephantiasis elimination. 2017;2(1):57-72.

21. Erlan A. Promosi kesehatan dalam pengendalian filariasis. $J$ Balaba. 2014;10(02):89-96. 